\title{
Nathan Isaacs
}

Nathan Isaacs, of the faculty of the Graduate School of Business Administration, Harvard University, and a member of the Business Historical Society, died on Thursday, December 18, 1941, after an illness of several months. He left his wife, Ella Davis Isaacs, and a daughter, Carol. Professor Isaacs was one of Harvard University's great appreciative and critical scholars; students of law, business, and Hebrew literature profited immeasurably from his generous and kindly life. His place on the faculty of the Business School can never be filled.

One of eight sons of Abraham and Rachel Isaacs, Nathan Isaacs was born on July 10,1886 . He began his collegiate career at the University of Cincinnati, where he received his A.B. degree in 1907, A.M. degree in 1909, and Ph.D. and LL.B. degrees in 1910. A member of the Ohio bar, he practised law in Cincinnati for two years, returning to the Cincinnati Law School in 1912 as Assistant Dean and Professor of Law. During the first World War he served as a captain in the Military Intelligence Division. His first association with Harvard University came in 1919 as the Thayer teaching fellow at the Law School. The following year he received the S.J.D. degree from Harvard and joined the faculty of the University of Pittsburgh, of which he was a member for three years. Returning to Harvard University in 1923, he became Professor of Business Law in 1924.

Professor Isaacs was a man of broad interests and wide influence. A member of Phi Beta Kappa, the American Academy of Arts and Sciences, the American Bar Association, and the American Arbitration Association, he contributed to these and to many other learned societies out of the rare intellectual combinations that were his. In addition to his work as a scholar and a teacher, he was an able administrator. That he was appreciated 
as' well by business men and firms was recognized in his appointment as director of Gimbel Brothers. In recent years his great efforts on behalf of Jewish refugees drew heavily on his energy and affected him deeply. It is a fair measure of his life to say that in his efforts on behalf of institutions, causes, and other people, he forgot himself.

Myles L. Mace, Harvard University. 